\title{
Air and Space Law Education: Preparing for the Future in China, Indonesia, Italy and Thailand
}

\author{
Ridha Aditya Nugraha ${ }^{1}$, Dejian Kong ${ }^{2}$, Gaia Guiso ${ }^{3}$, Lalin Kovudhikulrungsri ${ }^{4}$ \\ ${ }^{1}$ Air and Space Law Studies - International Business Law Program, Universitas Prasetiya Mulya, Indonesia. \\ E-mail: ridha.nugraha@prasetiyamulya.ac.id \\ 2 Research Institute of Air and Space Law, China University of Political Science and Law, China. E-mail: \\ d.kong@cupl.edu.cn \\ 3 The Libera Università Internazionale degli Studi Sociali Guido Carli, Alumna, Italy. E-mail: \\ gaia.guiso@alumni.luiss.it \\ 4 Faculty of Law, Thammasat University, Thailand.E-mail: Ialin@staff.tu.ac.th
}

\begin{abstract}
Aerospace technology has developed rapidly within the last decade. Facing the future, there is an urgency to balance aerospace technology developments with providing sufficient human resources through education, in this context from the perspective of air and space law. From east to west, this article elaborates on air and space law education in four countries with different experiences in aerospace activities, namely China, Thailand, Indonesia, and Italy. The development of higher education in conducting such programs is essential to ensure that the national aerospace industry will never lack proper human resources from its own nationals, including professionals with specific air and space law expertise. Furthermore, higher education has a significant role in bridging the industry with recent developments and advising the government in setting up aviation and space policies, as in the successful case of China and Italy. In the end, this article provides policy recommendations on promoting air and space law in higher education.
\end{abstract}

Keywords: Air Law; Aviation Law; Education; Space Law

\section{Introduction}

Richard Branson, the pioneer behind Virgin Galactic, reached the heights of $85 \mathrm{~km}$ above the earth together with the other five people on the $12^{\text {th }}$ of July 2021 to experience zero gravity. Eight days later, Jeff Bezos's Blue Origin followed through with a vertical launch which brought the New Shepard space vehicle passing the imaginary von Karman line at the heights of $100 \mathrm{~km}$. On $16^{\text {th }}$ September 2021, Space-X launched the first all-tourist or civilian crew into orbit. The success of multiple commercial spacecraft in performing suborbital flights has convinced the world that the era of space tourism is just starting.

In parallel, Elon Musk is working on Starlink, a constellation of small satellites in low-earth orbit (LEO) with the aim to provide internet globally. Beta service has been conducted since earlier this year to provide high speed internet, including remote and less developed 
areas, with various data speeds between $50 \mathrm{Mb} / \mathrm{s}$ to $150 \mathrm{Mb} / \mathrm{s}^{1}{ }^{1}$ The success of this project means more small satellites will be launched in the LEO. Not to mention the introduction of the United States' Space Force in 2019 and the ambitions of space faring nations to dominate space mining. These emerging space issues trigger the necessity of space law on commercial private space industry in both international and domestic spheres.

The events happening on earth are also important to follow. Due to its nature, aviation issues feel closer and are more realistic to some people. At the moment, the aviation industry is paused and restarting during the Covid-19 pandemic. Prior to the pandemic in March 2020, seamless connectivity between regions and continents have grown. The global aviation industry had to face various challenges: from determining fair competition, disputes on national airlines subsidy (also known as state-aid), enhancing passengers' rights through multiple efforts in ratifying the Montreal Convention of $1999^{2}$, issues on aircraft manufacturer subsidies, acceptance and in the same time reluctance towards the open skies concept, to flight security issues following to Malaysia Airlines MH17 shutdown in 2014 and Ryan Air FR4978 forced down in Belarusian skies earlier this year. As the aviation industry encompasses a wide variety of businesses, not only airlines, other sectors inter alia airport operators, ground handling, and maintenance repair and overhaul (MRO) are also as important. As the examples can be multiplied, the knowledge of air law is essential for similar problems.

The world wonders about the post-pandemic new face of the aviation industry because adaptations and changes shall occur. Meanwhile, in outer space, humanities are facing space (race) 4.0. The latter is defined as an era where the number of space actors increased and become more diverse due to various factors, such as the emergence of private sectors, participation with academia, and social interactions. ${ }^{3}$ The recent developments have shown the importance of human resources with profound knowledge in both air and space law.

Universities are the gateway for supplying future demands on aviation and space sectors. This article shall focus on air and space law performed at higher education, both from the bachelor (undergraduate) and masters (postgraduate) programs. A glimpse of doctoral studies is also presented. Practices in four countries, from east to west - China, Thailand, Indonesia, and Italia - shall be presented. These four countries have engaged in aviation or space sectors for a long history.

China aims to become the new axis in space activities by dispatching three taikonauts (astronauts) to its Tiangong space station in July 2021, and it is already one of the top five

1 Starlink. Order Starlink. https://www.starlink.com/. [Accessed 17 July 2021].

2 Convention for the Unification of Certain Rules for International Carriage by Air, done in Montreal, 28 May 1999. https://www.iata.org/contentassets/fb1137ff561a4819a2d38f3db7308758/mc99-fulltext.pdf.

3 European Space Agency. What is 4.0? https://www.esa.int/About Us/Ministerial Council 2016/What is space 4.0. [Accessed 17 July 2021]. 
largest aviation markets in the world. ${ }^{4}$ Thailand relies on the aviation sector for years with a success in bringing the highest number of foreign tourists to the Association of SouthEast Asia Nations (ASEAN) prior to the pandemic, and its cabinet just approved the space affairs bill in July 2021. Indonesia, also a part of ASEAN, relies on the aviation sector for establishing seamless domestic connectivity due to its archipelagic status; and in parallel developing its space economy and spaceport. Last but not least, Italy has a long history in both aviation and space sectors, with experience in the aircraft manufacturing industry and legislations for the former and a significant contribution for the European Space Agency (ESA) for the latter.

Therefore, this article shall explore the progress of each country's air and space law education. Their experience shall become lessons for others. One important sequence to mention is how Indonesia's diplomatic efforts succeeded in establishing the archipelagic state concept in the United Nations Convention on the Law of the Sea (UNCLOS) $1982^{6}$. However, a lack of education on the law of the sea resulted in the lack of potential human resources to fulfil President Jokowi's ambition to become a maritime fulcrum in $2014 .^{7}$ This story must not be repeated in the aviation and space sector, particularly in welcoming the aviation industry post-pandemic and space race 4.0.

\section{China: Balancing Rapid Aviation and Space Activities with Law Education}

China is stepping forward as an aviation and space powerhouse; and the academic research, legal practice, and higher education in the field of air and space law is growing accordingly. Unlike on the international stage, the birth of China's air and space law was not so clear and the development of both fields was out of sync. The theory and legislation of air law originally started at the beginning of the $20^{\text {th }}$ century, when aircraft were only starting to fly and the aviation administration was formed afterwards. However, space activities and relevant legal and policy development have started since 1949, when the People's Republic of China was established.

At present, China has established a comprehensive legal system regarding air law, in particular the Civil Aviation Law of the People's Republic of China ${ }^{8}$. However, in regards to space law, China still has a long way to improve, considering the fact that it is still one

4 Centre for Aviation (16 April 2020). China becomes the largest aviation market in the world. https://centreforaviation.com/analysis/reports/china-becomes-the-largest-aviation-market-in-theworld-521779. [Accessed 17 July 2021].

5 Bangprapa, Mongkol (14 July 2020). Cabinet approves draft Space Affairs Bill. Bangkok Post. https://www.bangkokpost.com/thailand/general/2148599/cabinet-aproves-draft-space-affairs-bill. [Accessed 1 August 2021].

6 United Nations Convention on the Law of the Sea. Concluded in Jamaica, 10 December 1982. https://www.un.org/depts/los/convention agreements/texts/unclos/UNCLOS-TOC.htm.

7 Laksmana, Evan (8 November 2019). Indonesia as "Global Maritime Fulcrum": a Post-Mortem Analysis. Asia Maritime Transparency Initiative. https://amti.csis.org/indonesia-as-global-maritime-fulcrum-apost-mortem-analysis/. [Accessed 17 July 2021].

8 Civil Aviation Law of the People's Republic of China, adopted at the 16th Session of the Standing Committee of the Eighth National People's Congress on October 30, 1995; and was last amended on April 29, 2021. 
of the few space powerhouses that lack basic national space legislation. The discussion on air and space law education in China below is based on the background above.

\subsection{Air and Space Law Education Program in China}

China has a comprehensive, yet complicated system of legal education of which air and space law occupies a small part. In this country, this subject is not yet an independent branch of law. Air law and space law have been treated as a chapter of public international law for the purpose of teaching undergraduate program. Air and space lawcentred programs in general starts at postgraduate level. Despite this, both master and doctoral programs in air and space law are mostly put in the context of international law. Postgraduate students in air and space law will not be given separate degrees, but rather be awarded a master or doctoral degree in international law. In this context, air and space law programs in China are held by the following types of universities.

\subsubsection{Universities of Political Science and Law}

In order to train legal professionals and improve academic research in law, China established five political science and law universities that offer postgraduate courses in air and space law. Three of the most reputable ones are described below.

First, the China University of Political Science and Law (CUPL), which earns the reputation as the "the most prestigious law school for cultivation of legal talent in China". ${ }^{9}$ This university established the Research Institute of Air and Space Law in 2007. CUPL offers a master's in international law including air and space law which is considered an independent research direction, in parallel with the more traditional branches of international law in China, inter alia private international law, public international law, and international economic law.

Second is the East China University of Political Science and Law (ECUPL). This university is also a powerhouse of air and space law education in China, offering an air and space law course and maintaining a high reputation in the field of legal academic research. The third is the Northwest University of Political Science and Law (NWUPL) which established a research institute of air and space law named after Professor Bin Cheng, a Chinese-born British world scholar in international air and space law. The NWUPL researchers guide master and doctoral students who are conducting advanced research in air and space law.

In addition, other universities non-exclusive to political science and law also take part in the development of air and space law. The Institute of International Law - Wuhan University, which contributes to important academicians in the field of international law, has an air and space law education and legal research program which are on the rise. Shenzen University, which offers general courses, also has master and doctoral students in both air and space law.

9 China University of Political Science and Law. Brief Introduction. http://en.cupl.edu.cn/About CUPL/Brief Introduction.htm. [Accessed 14 August 2021]. 


\subsubsection{Universities with Aeronautics and Astronautics Subjects}

Besides the aforementioned universities which focus on legal research and education, air and space law is also being taught in Chinese universities with aeronautics and astronautics subjects. For example, both the Beihang University (formerly known as Beijing University of Aeronautics and Astronautics, BUAA) and Nanjing University of Aeronautics and Astronautics (NUAA) have quite a prominent role in air and space law education and research, not to mention their leading status in the subjects of aeronautics and astronautics. Furthermore, the Regional Centre for Space Science and Technology Education in Asia and the Pacific (China - affiliated to the United Nations), hosted by the BUAA, offers a master degree for international students (non-Chinese), providing the opportunity to study space law and policy under Beihang University.

The other universities are the Beijing Institute of Technology (BIT) and the Harbin Institute of Technology (HIT). Both are reputable universities offering master's courses in space law alongside aviation and space technology. Furthermore, the Civil Aviation University of China (CAUC) and Civil Aviation Management Institute of China (CAMIC), as the two most important organizations under the Civil Aviation Administration of China (CAAC), play an important role in air law education and air law staff training respectively.

\subsubsection{Academic Institutes and Society}

Several academic institutes and society take part in fostering the development of air and space law even though they do not offer a degree in air and space law. For example, academic institutes, such as the Aviation Law Research Association of the China Law Society and China Institute of Space Law, hold annual meetings in air law and space law. It is an opportunity for academia and professionals to exchange opinions.

Furthermore, the Asia-Pacific Space Cooperation Organization (APSCO) as an international organization in China also contributes to the development of air and space law - both in education and legal research. For example, APSCO and Beihang University have initiated APSCO Master Program on Space Technology Applications (MASTA Program) since 2009 as an operational program for applicants from APSCO Member States. ${ }^{10}$ Currently, Beihang University has a number of students in the program, not only from China but also from numerous other countries.

\subsection{Career and Opportunities: Still a Blue Ocean}

The available jobs for law students in China include a number of fields, but the common requirement to practice law is to receive the Legal Professional Qualification Certificate after passing the National Judicial Examination of China. Some law graduates would attend the National Examination for Admissions to the Civil Service and then work as a governmental officer. For air and space law students, agencies governing aviation and space affairs at both central-governmental level, such as the CAAC and China National Space Administration, and local-governmental level are the best choices to practice their

10 APSCO, Degree Education. http://www.apsco.int/html/comp1/content/Education/2018-07-02/41-1641.shtml. [Accessed 14 June 2021]. 
major knowledge. However, the juridical system - including courts and procuratorates does not offer a broad platform for the air and space law practice because the number of air and space law cases are relatively small. China does have a special court for railway transport legal affairs, but the country has yet to set up an aviation court or space court like the one recently established in Dubai, United Arab Emirates (UAE) for commercial disputes in the cosmos. ${ }^{11}$

Fortunately, in the domain of aviation and space industry, state-owned enterprises constitute the main power in the market. Some graduates of air and space law may find employment through mega enterprises or enterprise cluster such as the China Aerospace Science and Technology Corporation, China Aerospace Science and Industry Corporation Limited, Air China, China Eastern Airlines, China Southern Airlines and Capital Airports Holdings Company Limited. In addition, air and space law graduates may also work as a company lawyer in private commercial companies, such as a series of smaller private airlines and start-up commercial space companies. Apart from that, arbitration institution such as the Shanghai International Aviation Court of Arbitration (SHIAC) may also help increase job posts related to air law - as opposed to space law because space-related commercial disputes are so far quite rare in China.

Admittedly, there is less legal employment opportunities in air and space law compared to other legal departments in China. At the same time, air and space law is not an ideal field for fresh graduates to start a career, mostly due to less business opportunities barrier in the industry. Nonetheless, the careers in air and space law in China cannot be described as 'bad' because of the two facts: firstly, there is only a few annual graduates in this major, which means less competitive pressure within the community itself; secondly, the knowledge of air and space law is so specific that it is very hard for legal staff without the knowledge in said sectors to apply for jobs in air and space law, which also means less competitive pressure outside of the community.

\section{Thailand: The Importation of Knowledge to the Creation of Specialized Area in Academia and Practice}

People in Thai academia sometimes refer to air law and space law as a single subset; however, in terms of legal development, each branch possesses its own different story. For public international air law, Thailand attended the Chicago Conference as an observer and ratified the Convention on Civil Aviation of $1944{ }^{12}$ (the "Chicago Convention of 1944") as early as $1947 .{ }^{13}$ Before becoming a party to the Chicago Convention, there

11 Dubai International Financial Centre, Courts of Space launches into orbit in support of global space economy. https://www.difc.ae/newsroom/news/courts-space-launches-orbit-support-global-spaceeconomy/. [Accessed 15 June 2021].

12 International Civil Aviation Organization Website. (1944). Convention on International Civil Aviation. https://www.icao.int/publications/documents/7300 orig.pdf. [Accessed 17 July 2021].

13 International Civil Aviation Organization Website. The Postal History of ICAO. https://applications.icao.int/postalhistory/1944 the chicago convention.htm. [Accessed July 17, 2021]; International Civil Aviation Organization Website. List of Parties to the Convention on 
existed a domestic air law. Then, it implemented the Chicago Convention into the Air Navigation Act B.E. 2497 (1954).

For private international air law, particularly a law on international carriage by air, even though Thailand considers itself one of the region's global hubs for air travel, it has never been bound by the Convention for the Unification of Certain Rules Relating to International Carriage by Air of $1929^{14}$ (the "Warsaw Convention of 1929") and only recently ratified the Convention for the Unification of Certain Rules for International Carriage by Air of $1999^{15}$ (the "Montreal Convention of 1999") in August 2017. ${ }^{16}$ In the subject of international space law, Thailand is a party to two space law treaties, namely the Outer Space Treaty of $1967^{17}$ and the Rescue Agreement of $1968^{18}$. Furthermore, as of May 2021, a specific national space legislation is on the process of being drafted. ${ }^{19}$

Since aviation law is a special branch of international law, the Thai government once in a while awards scholarships to Thai law graduates to pursue an advanced study in air law and then return to work for a civil aviation authority or other related government sectors. These students mainly study at the Institute for Air and Space Law, McGill University, Canada. ${ }^{20}$ As a result, the knowledge of space law is their by-product. These individuals become workforces for the civil aviation authority as well as guest lecturers at universities. Meanwhile, there are lecturers of air and space law who graduated in general public international law and have either expanded their field of interest or have enrolled in courses on air and space law from other overseas universities.

International

Civil

Aviation.

https://www.icao.int/secretariat/legal/List\%20of\%20Parties/Chicago EN.pdf. [Accessed 17 July 2021].

14 International Air Transport Association (IATA) Website. (1929). Convention for the Unification of certain rules relating to international carriage by air. https://www.iata.org/contentassets/fb1137ff561a4819a2d38f3db7308758/mc99-full-text.pdf. [Accessed 17 July 2021].

15 International Air Transport Association (IATA) Website. (1999). Convention for the Unification of Certain Rules for International Carriage by Air. https://www.iata.org/en/policy/smarter-regulation/mc99/. [Accessed 17 July 2021].

16 International Civil Aviation Organization Website. List of Parties to the Convention for the Unification of Certain Rules for International Carriage by Air. https://www.icao.int/secretariat/legal/List\%20of\%20Parties/Mtl99 EN.pdf. [Accessed 17 July 2021].

17 United Nations Office for Outer Space Affairs Website. (1967). Treaty on Principles Governing the Activities of States in the Exploration and Use of Outer Space, including the Moon and Other Celestial Bodies. https://www.unoosa.org/oosa/en/ourwork/spacelaw/treaties/introouterspacetreaty.html. [Accessed 17 July 2021].

18 Agreement on the Rescue of Astronauts, the Return of Astronauts and the Return of Objects Launched into Outer Space, Opened for signature in London, Moscow, and Washington, D.C. on 22 April 1968. https://aerospace.org/sites/default/files/policy archives/Assistance\%20Agreement\%20Apr68.pdf.

19 Mongkol Bangprapa. (2021). Cabinet approves space bill. https://www.bangkokpost.com/thailand/general/2148811/cabinet-approves-space-bill. [Accessed 17 July 2021].

20 McGill Institute of Air \& Space Law Website. Class Lists by Country. https://www.mcgill.ca/iasl/about/alumni/list/country\#thailand. [Accessed 17 July 2021]. 
In regards to space law, the increasing importance of outer space activities and the cooperation with China are the motivating factors for the Thai government to finance their personnel to study space law in Beihang University, China.

\subsection{Air and Space Law Education}

Almost every university in Thailand has a faculty of law or at least a law department. A study of air and space law can be in a faculty of law or a faculty related to aerospace science. For example, students at the bachelor of science program in aviation technology management, Kasetsart University, must study aviation law and regulations. ${ }^{21}$ In this section, the attention is strictly paid to courses provided at the undergraduate level at the law school in both public and private universities around Thailand.

Among the 20 selected universities, 12 universities do not deliver courses directly linked to air and space law. Despite no air and space law course, certain topics can touch upon air and space law. A logistic law class at Naraesuan University covers transportation by air. ${ }^{22}$ An international trade law class at University of Phayao also includes air transportation. ${ }^{23}$ Yet, the law on air carriage is taught altogether with other means of transportation and from a carriage of goods perspective. Two universities, namely Ramkhamhaeng University - a public university ${ }^{24}$ - and Dhurakij Pundit University - a private university ${ }^{25}$ - offer an air-law-only class as an elective course. Similarly, both teach only the public international air law aspect while excluding the private air law aspect.

Two other universities solely offer a space law course; namely the University of the Thai Chamber of Commerce ${ }^{26}$ and Udon Thani Rajabhat University ${ }^{27}$. Thammasat University,

21 Faculty of Engineering Kasetsart University Website. (2017). Bachelor of Science Program in Aviation Technology Management. https://www.eng.ku.ac.th/wp-content/uploads/2020/10/BThai-25ATSpecial.pdf. [Accessed 16 August 2021].

22 Division of Academic Affairs Naresuan University. (2017). Bachelor of Laws Program. https://www.acad.nu.ac.th/acad v2.1/ACAD AcademicDevelop/acadcd/StdManual 2560/files/cluster /soc/01 laws/60/\%E0\%B8\%A1\%E0\%B8\%84\%E0\%B8\%AD.2-\%E0\%B8\%AB\%E0\%B8\%A5\%E0\%B8\%B1\%E 0\%B8\%81\%E0\%B8\%AA\%E0\%B8\%B9\%E0\%B8\%95\%E0\%B8\%A3\%E0\%B8\%99\%E0\%B8\%B4\%E0\%B8\%95 \%E0\%B8\%B4-2560.pdf. [Accessed 16 August 2021].

23 School of Law University of Phayao. (2020). Bachelor of Laws Program. http://www.law.up.ac.th/FileUpload/\%E0\%B8\%AB\%E0\%B8\%A5\%E0\%B8\%B1\%E0\%B8\%81\%E0\%B8\%AA \%Е0\%B8\%B9\%Е0\%B8\%95\%Е0\%B8\%A3-\%E0\%B8\%99.\%E0\%B8\%9A.-\%E0\%B8\%9B\%E0\%B8\%A3\%E0\%B8 \%В1\%Е0\%В8\%9A\%Е0\%В8\%9B\%Е0\%В8\%А3\%Е0\%В8\%B8\%Е0\%В8\%8763-\%Е0\%B9\%81\%Е0\%B8\%81\%E0\%B9\%89\%E0\%B9\%84\%Е0\%B8\%82-10-363 637249003663453419.pdf. [Accessed 16 August 2021].

24 Faculty of Law Ramkhamhaeng University Website. (2020). Bachelor of Laws and Associate Degree Program in Laws. http://www.law.ru.ac.th/document/bachelor.pdf. [Accessed 16 August 2021].

25 Law Pridi Dhurakij Pundit University Website. (2020). Bachelor of Laws Program. https://law.dpu.ac.th/upload/content/files/Coursestructure-Law2563.pdf. [Accessed 16 August 2021].

26 UTCC School of Law Website. (2021). Bachelor of Laws Program. https://law.utcc.ac.th/IIb/\#1589449413315-6c8e8c13-1f1f. [Accessed 16 August 2021].

27 Faculty of Humanities and Social Sciences, Udon Thani Rajabhat University Website. (2021). Bachelor of Laws. $\quad$ http://human.udru.ac.th/website/wpcontent/uploads/2021/07/\%E0\%B8\%84\%E0\%B8\%B9\%E0\%B9\%88\%E0\%B8\%A1\%E0\%B8\%B7\%E0\%B8\% AD\%E0\%B8\%AA\%E0\%B8\%B2\%E0\%B8\%82\%E0\%B8\%B2\%E0\%B8\%A7\%E0\%B8\%B4\%E0\%B8\%8A\%E0\%B 
Chulalongkorn University, Mae Fah Luang University, and Assumption University are equipped with air and space law courses. These four universities each have their own distinct characters; while Thammasat University and Chulalongkorn University are the two most prominent public law schools situated in the capital, Mae Fah Luang University only founded the school of law around 20 years ago in the northern part of Thailand. Unlike the others, Assumption University is a private university.

From a detailed survey, they are slightly different on the credit and design of the course. These universities can be distinguished into two categories in terms of what courses they offer. The first category consists of those having an air law course separated from a space law course, inter alia Thammasat University, Chulalongkorn University, and Mae Fah Luang University. ${ }^{28}$ The second category consists of only Assumption University which provides air and space law as a single course in a two-credit class. ${ }^{29}$ Though Thammasat University previously taught air and space law together in a three-credit course, mention must be made to the recently revised curriculum in 2018 which resulted in the separation of courses attributed to the first category of universities. ${ }^{30}$

Strictly focusing on the first category where air law and space law is taught in different courses, each university within the category assigns a varying number of credits to the course. Typically, each semester lasts 15 weeks; the number of recorded credits is proportional to the number of hours per week. Chulalongkorn University assigns two credits for each course, while the other two universities award three credits. Interestingly, Mae Fah Luang's and Chulalongkorn's descriptions of air law course are identical, with both addressing public and private international air law aspects. ${ }^{31}$ Thammasat's aviation law class focuses on the public aspect only because another

8\%B2-\%E0\%B8\%99\%E0\%B8\%B4\%E0\%B8\%95\%E0\%B8\%B4\%E0\%B8\%A8\%E0\%B8\%B2\%E0\%B8\%AA\%E0 \%B8\%95\%E0\%B8\%A3\%E0\%B9\%8C-64.pdf. [Accessed 16 August 2021].

28 Office of the Register Website, Thammasat University. (2018). Bachelor of Laws Program. https://reg.tu.ac.th/th/Picture/AttFile/d22829be-05e5-4089-8d3f-5267c9656827. [Accessed 16 August 2021]; Law Chula Website. (2020). Bachelor of Laws Program. https://www.law.chula.ac.th/wpcontent/uploads/2021/02/คู่มือหลักสูตรปริญญญาตรี-ปีการศึกษา-2563.pdf. [Accessed 16 August 2021]; Registrar Division Mae Fah Luang University Website. (2012). Bachelor of Laws Program. https://reg.mfu.ac.th/registrar/program info 1.asp?f $\mathrm{cmd}=2 \&$ levelid=3\&programid $=553160100 \& \mathrm{fac}$ ultyid=16\&programyear=2555\&programname=\%B9\%D4\%B5\%D4\%C8\%D2\%CA\%B5\%C3\%BA\%D1\%B3 \%B1\%D4\%B5\&facultyname=\%B9\%D4\%B5\%D4\%C8\%D2\%CA\%B5\%C3\%EC\&levelname=\%BB\%C3\%D4\% AD\%AD\%D2\%B5\%C3\%D5. [Accessed 16 August 2021].

29 AU School of Law Website. (2021). Bachelor of Laws Program. http://www.law.au.edu/program-Ilbthai.html. [Accessed 16 August 2021].

30 Office of the Register Website, Thammasat University. (2013). Bachelor of Laws Program. https://reg.tu.ac.th/th/Picture/AttFile/c9b0a12f-81e0-4d47-92ba-079e30983576. [Accessed 16 August 2021].

31 Registrar Division Mae Fah Luang University Website. (2021). Bachelor of Laws Program. https://reg.mfu.ac.th/registrar/class info 2.asp?courseid=1705215273\&backto=home\&nosection=1. [Accessed 16 August 2021]; Law Chula Website. (2020). Bachelor of Laws Program. https://www.law.chula.ac.th/wp-content/uploads/2021/02/คู่มือหลักสูตรปริญญาตรี-ปีการศึกษา-2563.pdf.

[Accessed 16 August 2021]. 
specific elective class on the law on contracts of carriage by air is available. ${ }^{32}$ Both aviation law and space law classes of Thammasat University are subject to a pre-condition that students must study public international law earlier. ${ }^{33}$ Students can meet this prerequisite no sooner than the second semester of their third year of a four-year degree.

Finally, an advanced master's degree in air and space law is unavailable. According to a survey of nine universities' curricula, two-thirds offer at least one course on air law or space law. ${ }^{34}$ For the master's degree, Assumption University and the University of the Thai Chamber of Commerce only offer an air law course. ${ }^{35}$ Unlike the undergraduate level, Thammasat University, Chulalongkorn University, Ramkhamhaeng University, and Mae Fah Luang University offer a single air and space law class in their graduate programs. ${ }^{36}$ In Thailand, it is compulsory for graduate students to write a thesis; therefore, some students choose to research in either public or private aspects of air or space law.

\subsection{Career and Opportunities}

Law graduates with air and space law knowledge can serve in both public and private practices; however, they must also be equipped with other fields of law. An in-house lawyer in an airline, for example, may entail not only knowledge of the Montreal Convention and aircraft financing but also a basic understanding of company law. For a specialized profession in air law, with the ratification of the Montreal Convention of 1999,

32 Office of the Register Website, Thammasat University. (2018). Bachelor of Laws Program. https://reg.tu.ac.th/th/Picture/AttFile/d22829be-05e5-4089-8d3f-5267c9656827. [Accessed 16 August 2021].

33 Office of the Register Website, Thammasat University. (2018). Bachelor of Laws Program. https://reg.tu.ac.th/th/Picture/AttFile/d22829be-05e5-4089-8d3f-5267c9656827. [Accessed 16 August 2021].

34 Chiang Mai University, NIDA, and Dhurakij Pundit University do not offer any. See Faculty of Law, CMU Website. (2018). Master of Laws Program. https://www.law.cmu.ac.th/law2011/downloads/mastercourse-structure2561.pdf. [Accessed 16 August 2021]; NIDA School of Law Website. (2017). Master of Laws Program. http://law.nida.ac.th/statics/ui/files//336c373bab696fcf211eaf3eb3dcd989.pdf. [Accessed 16 August 2021]; Dhurakij Pundit University Website. (2019). Master of Laws Program. https://www.dpu.ac.th/IIm/documents/Master\%20of\%20Laws.pdf. [Accessed 16 August 2021].

35 AU School of Law Website. (2021). Master of Laws Program. http://www.law.au.edu/program-IImthai.html. [Accessed 16 August 2021]; UTCC School of Law Website. (2021). Master of Laws Program. https://law.utcc.ac.th/Il-m/\#1589449329451-ee8cff53-aeed. [Accessed 16 August 2021].

36 Office of the Register Website, Thammasat University. (2013). Master of Laws Program. https://reg.tu.ac.th/th/Picture/AttFile/c113296d-c2c6-4641-8c13-c0f1b28479be. [Accessed 16 August 2021]; Law Chula Website. (2019). Master of Laws Program. https://www.law.chula.ac.th/wpcontent/uploads/2019/06/น.ม-รายวิชาลงทะเบียนเรียนภาคการศึกษาต้น-ปีการศึกษา-2562.pdf. [Accessed 16 August 2021]; Faculty of Law Ramkhamhaeng University Website. (2017). Master of Laws. http://www.law.ru.ac.th/document/master.pdf. [Accessed 16 August 2021]; Registrar Division Mae Fah Luang University Website. (2012). Master of Laws Program. https://reg.mfu.ac.th/registrar/program info 1.asp?f cmd=2\&levelid=51\&programid=555160103\&fa cultyid=16\&programyear=2555\&programname=\%B9\%D4\%B5\%D4\%C8\%D2\%CA\%B5\%C3\%C1\%CB\%D2 \%BA\%D1\%B3\%B1\%D4\%B5+\%E1\%BC\%B9+\%A2\&facultyname=\%B9\%D4\%B5\%D4\%C8\%D2\%CA\%B5\%C3 \%EC\&levelname=\%BB\%C3\%D4\%AD\%AD\%D2\%E2\%B7+\%28\%C0\%D2\%A4\%BE\%D4\%E0\%C8\%C9\%29. [Accessed 16 August 2021]. 
there is a chance that judges and lawyers should learn more about private air law. There is no specialized law firm on air and space law; however, big law firms, especially those affiliated with international network, do offer aircraft finance and leasing consultation.

Nevertheless, it is foreseeable that the government's initiative on the Eastern Economic Corridor, where aviation industries and aerospace technology will become its new Scurve industries, ${ }^{37}$ will spark a need for lawyers with experience in air and space law. Another supporting reason is the objectives in the national space bill to promote private participation in space activities and support the space economy.

\section{Indonesia: In Need of a Solid Foundation in Developing Air and Space Law Education}

Indonesia becomes the first ASEAN Member States to establish a national space agency, namely the National Institute of Aeronautics and Space (Lembaga Penerbangan dan Antariksa Nasional - LAPAN) back in 1963. President Soekarno's far leading vision on aerospace activities as the medium to unite the archipelago had led in the establishment of LAPAN just five years after the United States National Aeronautics and Space Administration (NASA) was founded. In 1976, Palapa A1 satellite, which was aimed to improve the national communications, was successfully launched, marking Indonesia as the first developing country to operate its own domestic satellite system. Afterwards, Indonesia found that satellite functions are essential, and has launched more than 20 satellites to different orbits since then.

In 2013, Indonesia finally enacted the Indonesian Space Law ${ }^{38}$ to cope with the urgency to regulate space activities in a national level. Such space law established a legal certainty on space activities; especially since prior to that Indonesia was already a signatory of all four outer space treaties besides the Moon Agreement of $1979^{39}$. As of July 2021, LAPAN was in progress of drafting two government regulations, namely on space commercialization and spaceport.

Indonesia has a long history in aviation. Prior to Covid-19 pandemic, the International Air Travel Association (IATA) projected that Indonesian aviation market would be the fourthlargest globally by 2039. ${ }^{40}$ The ASEAN Economic Blueprint $2025^{41}$ which encourages seamless connectivity within the region, in parallel with the rapid development of low-

37 The Eastern Economic Corridor of Innovation Website. (2021). Focused Industries. https://www.eeci.or.th/en/home/. [Accessed 16 August 2021].

38 The Republic of Indonesia, Law No. 21 of 2013 on Outer Space.

39 United Nations Office for Outer Space Affairs Website. (1967). Treaty on Principles Governing the Activities of States in the Exploration and Use of Outer Space, including the Moon and Other Celestial Bodies. https://www.unoosa.org/oosa/en/ourwork/spacelaw/treaties/introouterspacetreaty.html. [Accessed July 17, 2021].

40 Parama, Mardika (12 November 2020). Indonesia to have world's fourth-largest air passenger market by 2039: IATA. The Jakarta Post. https://www.thejakartapost.com/news/2020/11/11/indonesia-tohave-worlds-fourth-largest-air-passenger-market-by-2039-iata.html. [Accessed 14 August 2021].

41 The ASEAN Economic Community Blueprint 2025. https://aseandse.org/asean-economic-communityblueprint-2025/. [Accessed 28 August 2021]. 
fare airlines and the on-going liberalization progress, ${ }^{42}$ is an important instrument in meeting IATA's projections. With six new airports being built in $2022^{43}$ and revival of national airlines serving domestic flights, this situation also calls the establishment of aviation maintenance repair and overhaul (MRO).

The recent developments have shown the urgency of qualified human resources in the aviation industry, in this context those mastering air law and space law, in the near future. Higher education is the key, but unfortunately, Indonesian universities is lacking in teaching both subjects. The law education system needs to overcome several barriers, among others, administrative issues and the lack of aerospace considerations in public policy.

\subsection{Air and Space Law Education: The Long and Winding Road}

In the early years of the Republic, the access to education was a privilege and there were not many universities. In 1964, Faculty of Law Universitas Padjajaran - a state university in Bandung, West Java - laid the foundation of air and space law education in Indonesia. ${ }^{44}$ The late Professor Priyatna Abdulrasyid became the key person in promoting air and space law during those times with the university. ${ }^{45}$ However, the teachings of those subjects have not been keeping up with the real-time demand.

The Indonesian universities can be classified into two categories: state universities and private universities. In general, the former category provides a more rounded subjects, among them is the faculty of law with various specializations, and tend to be welldeveloped due to the state budget allocation. But nowadays, more private universities especially the big ones - also has their own faculty of law.

In 2020, there were 2,136 higher education institutions listed in the Ministry of Education, Culture, Research and Technology database. ${ }^{46}$ From this number, there were 19 state universities and 15 private universities offering air and space law course on undergraduate level - most of them were located in the Java Island. ${ }^{47}$ Some state universities are Universitas Indonesia, Universitas Airlangga, Universitas Brawijaya, Universitas Gadjah Mada, Universitas Padjajajran, Universitas Pembangunan Nasional Veteran Jakarta, and Universitas Hasanuddin; while the private universities are, among others, Universitas Katolik Indonesia Atma Jaya, Universitas Dirgantara Marsekal

42 Nugraha, Ridha Aditya. The Indonesian Aviation Sector in the Realm of Liberalisation: The Long and Winding Road. In Aviation Law and Policy in Asia: Smart Regulation in Liberalized Markets (2021): 25368.

43 Rabbi, Cahya Puteri Abdi. (26 August 2021). Bangun Bandara hingga Pelabuhan, Kemenhub Alokasikan Rp 21,6 Triliun. https://katadata.co.id/maesaroh/berita/61275f793a3c4/bangun-bandara-hinggapelabuhan-kemenhub-alokasikan-rp-21-6-triliun. [Accessed 26 August 2021].

44 Universitas Padjajaran website. https://www.unpad.ac.id/2014/11/fakultas-hukum-unpad-peloporpendidikan-hukum-udara-dan-ruang-angkasa-sejak-50-tahun-lalu/. [Accessed 15 August 2021].

45 Ibid.

46 Directorate General of Higher Education, Ministry of Education and Culture. Klasterisasi Perguruan Tinggi Tahun 2020. http://lldikti6.id/wp-content/uploads/2020/09/KLASTERISASI-PT-2020.pdf. [Accessed 28 August 2021].

47 Data collected in January 2021 through each university's website, including air and space law course syllabus provided for public access. 
Suryadarma, Universitas Islam Bandung, Universitas Pancasila, Universitas Surabaya, Universitas Tarumanegara, and Universitas Prasetiya Mulya.

The variations between those universities are mostly centered around whether the air and space law course are offered as i.) a mandatory subject for all students; ii.) mandatory only for students specializing in transnational law or public and private international law; or iii.) merely a selective course. The first category is the least popular option, with both state and private universities mostly falling into the second category.

On a graduate level, air and space law generally becomes a topic of international law specalization. There is no institute attached to a university which offers air and space law specialization - in this context offering only air and space law related courses. The Indonesian graduate program in law (M.H.) lasts for two years or four semesters, which is a year longer than LL.M. program offered by worldwide universities. In terms of duration, pursuing master program in the country becomes less attractive; especially for non-academia in a competitive job-seeking environment. In regards to doctoral program, dissertation in air and space law topic could be pursued in any university under the condition that the person is able to find the right promotor. A four-year period is the regular timeline for pursuing doctoral degree. It must be highlighted that a doctoral position is not considered as a job in Indonesia.

\subsection{Career and Opportunities: More Opportunities are Needed}

Law graduates in air and space law face challenge in the limited job opportunities. Law firms practicing aviation law, in this context aircraft financing, do accept fresh graduates. However, the number of such firms is limited and they are mostly located in the capital city, Jakarta. Legal position openings in airlines, airports, ground handling, Directorate General of Civil Aviation - Ministry of Transportation, and the Indonesian Air Force do not require specific knowledge on air law. Students might hesitate to pursue air and space law specialization considering the lack of opportunity in the relevant field.

Specific space law positions are even more limited than air law. As of today, the only available positions are the ones affiliated with government agencies. Furthermore, the job opening is not for fresh graduate. For example, the Indonesian Space Agency or LAPAN requires a master or doctoral degree in law for their current application. No independent research institute or think-tank in air and space law has been established, making the opportunity even more scarce. It is possible that such circumstances will change if regulations pertaining to space commercialization are enacted in the near future, leading to more jobs opening for those with space law expertise. Currently, the draft of government regulation on space commercialization is being finalized by LAPAN. ${ }^{48}$

48 Siregar, El Renova Ed. and Ardes, Runggu Prilia (12 March 2020). Focus Group Discussion Pertama tentang Rancangan Peraturan Pemerintah tentang Kegiatan Komersial Keantariksaan. Center for Aerospace Policy Studies. https://puskkpa.lapan.go.id/index.php/subblog/read/2020/153/FocusGroup-Discussion-Pertama-tentang-Rancangan-Peraturan-Pemerintah-tentang-Kegiatan-KomersialKeantariksaan/news-list. [Accessed 17 September 2021]. 
In the end, taking part in a university to develop air and space law shall be the most realistic career path. However, the scale of development will depend on the extent of the government's political seriousness in instilling awareness regarding the matter.

\section{Italy: Moving to the Mature Foundation}

Spaceflight has been the subject of interest of many notable Italian scientists - especially in the military field - since the early twentieth century. ${ }^{49}$ Nevertheless, the birth of an Italian space program has been strictly intertwined with the academic institutionalization of the aeronautics science in $1954,{ }^{50}$ a circumstance that was the harbinger of the launch of the first ever Italian satellite. ${ }^{51}$

Nearly 60 years later, it can be asserted that that launch not only allowed Italy to become one of the very first countries in the world to operate its own artificial satellite, but even constituted the genesis of a long-term commitment to space activities, paving the way to the institutionalization and development of a national, dedicated and fully-fledged, space policy - and, by extension, of a space education.

Over time, the combination of a few factors made apparent that the space sector was turning into an increasingly complex area: not only from a technological perspective, but from a legal one as well. ${ }^{52}$ This meant not only enhancing the study of STEM ${ }^{53}$, but also the literacy of the legal framework in which space activities take place and stakeholders (on all, international organizations, governmental entities and private business) operate.

A mostly uncharted territory, the legal framework is slowly but constantly evolving, although not always keeping up with the faster evolution of technological capabilities. This is true on an international level and even more so within the national panorama, where the teaching of the preexisting curriculum of Maritime or Air law could not cover

49 The military scene represented the main driving force behind the pursuit of a national empowerment in space, as it was (and still is) the case for many other countries.

50 In 1954 the University of Rome created the first faculty chair of Aerospace Engineering in Italy. The program was placed under the direction of top aerospace engineer and military man Luigi Broglio. Today widely acknowledged as a front runner and champion of the Italian space activities during that era, Broglio engaged the Italian government in setting up a well-defined project (addressed as the "San Marco Program") to launch the nation's first satellite, the San Marco 1. See Sezione Roma 2. Gen. Isp. C. Genio Aeronautico Luigi Broglio. http://www.romadue-broglio.eu/biografia/. [Accessed 3 June 2021].

51 The launch successfully took place on December 15, 1964, thanks to the joint funding efforts of the National Research Council-Italian Space Commission and the NASA-Office of Space Science Applications of the United States, who also provided the launch vehicle for this purpose. See National Aeronautics and Space Administration. San Marco 1. https://nssdc.gsfc.nasa.gov/nmc/spacecraft/display.action?id=1964-084A. [Accessed 3 June 2021].

52 The intensification of the international cooperation, the increasing number and diversified quality of the stakeholders and the growing inter-relevance of the economic, political and social implications steaming from the furtherance of a national space policy, all contributed to the awareness that a larger emphasis should be given to the building of a space education in Italy.

53 An acronym standing for Science, Technology, Engineering and Mathematics. It was first adopted by the National Science Foundation of the United States in 2001. See Hallinen, J. (2015, October 21). STEM in Encyclopædia Britannica, Inc. (2021). https://www.britannica.com/topic/STEM-education. [Accessed 3 June 2021]. 
the many peculiarities of the legal ground of Space activities. A premise that could not but enforce the need that a Space law education gets acknowledgement as an academic scope in its own right.

\subsection{The Birth of Air and Space Law Education}

Air law can undoubtedly boast a long tradition in the Italian academic scene. The creation of the first prominent academic entity - and the first faculty chair - with regard to aeronautical law took place in 1927, at the initiative of the Italian Ministry of Foreign Affairs. ${ }^{54}$ It was named Institute of Aeronautics Law (Istituto di Diritto Aeronautico) ${ }^{55}$ and established as a branch of the Faculty of Law, Sapienza University of Rome (Sapienza Università di Roma), in the footsteps of similar institutions already operating in Europe. ${ }^{56}$ Such an institute was something unique of its kind, in the sense that it posed as the hub of a specialized law education at a time when the law school in Italy was hardly ramified into separate institutes. ${ }^{57}$ During that period, the teaching of maritime law was also officially granted a faculty chair, although it was treated as a branch of the private law and not put under the sphere of the Institute of Astronautics Law. ${ }^{58}$

In 1945, the definition of the Italian Air law into a Codice Della Navigazione ${ }^{59}$ - still in force today - set up the confluence of Maritime and Aeronautical law teaching into a single institute, namely the Istituto di Diritto Della Navigazione ${ }^{60}$, thus replacing the Istituto di Diritto Aeronautico. ${ }^{61}$ As conceived, this juridical ecosystem comprising and putting on the same level maritime, air and terrestrial transport law holds true to the present day. At least, in terms of doctrine, as the academic education, in the most recent years, goes in the direction of splitting the advanced teaching of those subjects into dedicated courses. ${ }^{62}$

On the other hand, the history of Italian space law education is much more recent and still largely unwritten; as an evidence, the first ever manual on space law authored in

54 Administrator. (n.d.), Diritto dei trasporti. Istituto di diritto della navigazione. http://www.dirittodeitrasporti.it/index.php?option=com content\&view=article\&id=34\&ltemid=63. [Accessed 3 June 2021].

55 Transl.: Institute of Aeronautical law.

56 They were located in Paris (France), Losanna (Switzerland) and Königsberg (Germany). See Tullio, L. (n.d.). Storia dell'Istituto. https://www.fog.it/istituto/storia.html. [Accessed 25 September 2021].

57 Tullio, L. (n.d.). Documenti per la storia dell'Istituto di diritto della navigazione dell'Università La Sapienza di Roma, p.1. https://www.fog.it/articoli/02-0125.pdf. [Accessed 3 June 2021].

58 Tullio, L. (n.d.). Documenti per la storia dell'Istituto di diritto della navigazione dell'Università La Sapienza di Roma, p.4. https://www.fog.it/articoli/02-0125.pdf. [Accessed 3 June 2021].

59 Transl.: Maritime and Air Law Code. The Italian Maritime and Air Law Code was promulgated by King Vittorio Emanuele III by Royal Decree of 30 March 1942, n. 327, and implemented multiple times since then.It collected a series of rules governing maritime transport and air navigation.

60 Transl.: Institute of Maritime and Air Law.

61 Tullio, L. (n.d.). Documenti per la storia dell'Istituto di diritto della navigazione dell'Università La Sapienza di Roma, p.6. https://www.fog.it/articoli/02-0125.pdf. [Accessed 3 June 2021].

62 Alippi, C., \& D’Amelio, M. (1938). AERONAUTICA in “Enciclopedia Italiana", (I, p. 594). https://www.treccani.it/enciclopedia/aeronautica res-2a49a99e-8b74-11dc-8e9d0016357eee51 \%28Enciclopedia-Italiana\%29/. [Accessed 3 June 2021]. 
Italian was published only in $2011 .{ }^{63}$ Furthermore, space law as a discipline is not yet part of the academic law routine in law faculties, but rather the subject of some advanced complementary (and mostly optional) courses to the international law curriculum, or even the focus of specialized postgraduate training. However, the current situation is steadily evolving and space law is becoming an important part of the law program in an increasing number of universities throughout Italy.

\subsection{Air and Space Law Curriculum in Italy: Current Overview}

Most universities offer courses on air law within their law faculty. Students usually have the possibility to customize their study program enrolling in such courses and obtaining further academic credits. ${ }^{64}$ Over the last five years, the University of Genoa ${ }^{65}$ (where the first faculty chair of aeronautical law was founded during the early decades of the twentieth century ${ }^{66}$ ), University of Verona ${ }^{67}$, University of Bergamo ${ }^{68}$, of University of Messina ${ }^{69}$, University of Ferrara ${ }^{70}$, University of Udine ${ }^{71}$, and University of Sassari ${ }^{72}$, among others, all provided advanced courses on aeronautical law.

So does Europe and the world's most ancient academic institution ${ }^{73}$, the University of Bologna $^{74}$, while the Sapienza University of Rome ${ }^{75}$ and the University of Milano Bicocca ${ }^{76}$ offered a wider-ranging course on maritime and air law. Other universities, although not featuring the subject in their programs, organize or host conferences on the topic or, as

63 It was authored by Sgrosso, G. C. (2011). Diritto internazionale dello spazio. LoGisma. See Società italiana di diritto internazionale. http://www.sidi-isil.org/wpcontent/uploads/2010/06/Presentazione10.pdf. [Accessed 3 June 2021].

64 Crediti formativi universitari (CFU). Such credits are sought by students to complete the program or stay on top of their grades while deepening the subject of their interest, also in view of future career choices and opportunities.

65 Università delgi studi di Genova, Laurea Magistrale a Ciclo Unico, Giurisprudenza - Genova. https://corsi.unige.it/7995. [Accessed 3 June 2021].

66 Also thanks to the work of lawyer and politician Pietro Cogliolo. See Fabbrini, F. (1982). COGLIOLO, Pietro in Dizionario Biografico degli Italiani - Volume 26 https://www.treccani.it/enciclopedia/pietrocogliolo \%28Dizionario-Biografico\%29/. [Accessed 3 June 2021].

67 Università delgi studi di Verona, Combined Bachelor's + Master's Degree in Law. https://www.corsi.univr.it/?ent=cs\&id=274\&lang=en. [Accessed 3 June 2021].

68 Università degli studi di Bergamo, La parola agli student - Scegliere. https://lm-giu.unibg.it/it. [Accessed 3 June 2021].

69 Università degli studi di Messina website. https://international.unime.it/. [Accessed 3 June 2021].

70 Università degli studi di Ferrara website. http://www.unife.it/giurisprudenza/giurisprudenza. [Accessed 3 June 2021].

71 Università degli studi di Udine website. https://www.uniud.it/en/uniud-international?set language=en. [Accessed 3 June 2021].

72 Università degli studi di Sassari website. https://www.unime.it/it/dipartimenti/giurisprudenza. [Accessed 3 June 2021].

73 The oldest universities in 10 European countries. (n.d.). https://www.study.eu/article/the-oldestuniversities-in-10-european-countries. [Accessed 3 June 2021].

74 Università di Bologna website. https://www.unibo.it/en/homepage. [Accessed 3 June 2021].

75 Università delgi studi di Roma "Sapienza" website. https://www.uniroma1.it/en/paginastrutturale/home. [Accessed 3 June 2021].

76 Università degli studi di Milano website. https://en.unimib.it/. [Accessed 3 June 2021]. 
it is the case of the University of Bari ${ }^{77}$, provide a postgraduate specialized education ${ }^{78}$ on aeronautical law and aerospace contracts.

Conversely, the relevance of space law teaching is still confined to a limited number of universities and institutions. These are the University of Padua ${ }^{79}$, the Sapienza University of Rome, and the Italian Society for the International Organization (Società Italiana per l'organizzazione Internazionale - SIOI), also in Rome ${ }^{80}$, where the course was introduced in 2009 and successfully reiterated since then. In addition, the University of Bologna chose a mixed approach by offering a course that combines air and space law. On a regular basis, the European Space Agency (ESA) shares on its official website an updated list ${ }^{81}$ of all national institutions, including Italy's, that deliver space law programs in Europe and abroad.

The vast majority of the air and space law educational courses is taught in Italian. To this date, there are very few exceptions, one of them being the aforementioned teaching provided in English by the University of Bologna. ${ }^{82}$ Given their nature as an advanced learning, usually the courses have an entry requirement in the basic knowledge of International Public Law ${ }^{83}$, especially when the target audience is composed of law, political science or international relations students. When the course allows for a more diversified audience background 8485 , the educational texture is also more multi-faceted. It can include an overview of the space economy as well as technical, scientific, and industrial basics.

Besides the international framework, a great focus is put on the inter-agency cooperation within the European Union and on Italy's role as a founding member state of the European Space Agency. In the case of SIOI, national institutions such as the Agenzia Spaziale Italiana (ASI) ${ }^{86}$ and the Istituto di Studi Giuridici Internazionali (ISGI) of the

77 Università degli studi di Bari website. https://www.uniba.it/english-version. [Accessed 3 June 2021].

78 These are the so-called Master, not to be confused with the Master's degree - which, in Italy, corresponds to the Laurea magistrale.

79 Università degli studi di Padua website. http://www.unipd.it/en. [Accessed 3 June 2021].

80 Società Italiana per I'organizzazione Internazionale website. https://www.sioi.org/?lang=en. [Accessed 3 June 2021].

81 European Space Agency, Institutions Teaching Space Law. http://www.esa.int/About Us/ECSL European Centre for Space Law/Institutions teaching Space Law. [Accessed 3 June 2021].

82 Università di Bologna, Course Unit Catalogue: Air and Space Law 2020/2021. https://www.unibo.it/en/teaching/course-unit-catalogue/course-unit/2020/461805. [Accessed 3 June 2021].

83 See for instance the University of Padua: European Space Agency, University of Padua. http://www.esa.int/About Us/ECSL - European Centre for Space Law/University of Padua. [Accessed 3 June 2021].

84 E.g. Engineering, Economics.

85 See for instance the Italian Society for the International Organization (SIOI): Società Italiana per l'organizzazione Internazionale, Master's Course in Space Institutions and Policies. https://www.sioi.org/master corsi/masteri-in-istituzioni-e-politiche-spaziali/?lang=en. [Accessed 3 June 2021].

86 Transl.: Italian Space Agency. 
Consiglio Nazionale delle Ricerche $(\mathrm{CNR})^{87}$ are directly involved in the planning of the course $^{88}$ and even provide lecturers and other educational assets.

Courses are mostly held in presence or designed to be blended (combination between presence and online course - in this context, before Covid-19 pandemic), although the latter is not so widely implemented. In most cases, there could be group sessions where the participants must work on a project ${ }^{89}$ and some other intermediate tests to assess the learning progress. At the end of the course, the students may be required to deliver a thesis on a topic of their interest.

As a part of the law program, there is usually the opportunity for a university exchange ${ }^{90}$ or an internship, taking advantage of the partnerships stipulated by their academic institution with Aerospace companies, national or international organizations and other universities. This allows students to earn professional experience whilst or after completing the main studies. The Italian Space Agency, among others, regularly makes available internship positions for students and recent graduates, besides offering financial support to top students who wish to advance their studies in the space field, in Italy or abroad. ${ }^{91}$ In some cases, fulfilling the internship can be a mandatory requirement to successfully completing the course.

\subsection{Career and Opportunities: A Network in Evolution}

Law graduates can either have an early approach to air or space law at university, or choose to specialize afterwards. Either way, the opportunities for a profession in such fields do not lack, although are still very a niche. The most typical is certainly the one of space lawyer or legal advisor. In Italy, there are a few law firms that practice air law specifically, mainly in big cities. On a much smaller scale, that is also true for space law, practiced in law firms mostly located in major cities such as Rome, Milan and Turin.

Other professions include working in the public sector for some national institutions, such as the Italian Space Agency or the Ente Nazionale per l'Aviazione Civile (ENAC) ${ }^{92}$, ministries ${ }^{93}$, or within European organizations such as the European Space Agency, which as well regularly sets up programs for students, recent graduates and young professionals in the early stages of their career. ${ }^{94}$

The academic environment offers a number of opportunities. Law graduates can enroll for a PhD and aim to work as university professors, researchers or - going beyond the law knowledge and calling in a deep geopolitical knowledge and evaluation skills - analysts.

87 Transl.: Institute for international legal studies (ISGI) of the National Research Council (CNR).

88 Società Italiana per l'organizzazione Internazionale website. https://www.sioi.org/primo-piano/masterin-istituzioni-e-politiche-spaziali-on-line-il-bando-per-3-borse-di-studio/?lang=en. [Accessed 25 September 2021].

89 E.g. researching and analyzing together a law case study.

90 E.g. Within the Erasmus program.

91 Agenzia Spaziale Italiana website. https://www.asi.it/en/education/academy/. [Accessed 3 June 2021].

92 Transl.: Italian Civil Aviation Authority.

93 E.g. The Ministry for Foreign Affairs, Ministry of Defense or Ministry of Economic Development.

94 European Space Agency, Careers at ESA. http://www.esa.int/About Us/Careers at ESA. [Accessed 3 June 2021]. 
Especially in the latter case, some of the main institutes of reference are the Centro Nazionale Ricerche (CNR), the Istituto per gli Studi di Politica Internazionale (ISPI) ${ }^{95}$, and the Istituto Affari Internazionali (IAI) ${ }^{96}$.

Finally, the private sector is evolving fast and this allows for an increasing demand of air and space law experts to advance the special interests of companies and private stakeholders. Throughout the Italian soil, regional districts have risen, whose main area of interest is the enhancement of the space economy on a local level, also thanks to public-private partnerships aimed at internationalizing local entities. Among those, the Distretto Tecnologico Aerospaziale (DTA) of the Apulia region ${ }^{97}$, of Campania ${ }^{98}$ and of Sardinia can be cited. ${ }^{99}$ The growing complexity of the framework often requires transversal theoretical and practical know-how, a collection of skills that transcend the exclusive knowledge of air and space law. This can be expected to be even more important in the future, as the Aerospace system in the country builds stronger and more reticulated than ever before.

\section{Challenges in Bridging the Air and Space Law Education with the Industry}

While all four aforementioned countries possess a unique background in air and space technology and law, they all share one similarity in connecting scholars and practitioners. The current situation in China, Indonesia, and Thailand is now obstructed by the fact that air and space law curriculum is merely perceived as a part of international law, even though the developments have constantly shown that air and space law, as a terminology, is a comprehensive concept that encompasses public law and private law, national law, and international law at the same time. By realizing its extensive scope, education and research in air and space law should include various systems of law instead of solely emphasizing on international law.

One of the main goals pertaining to air and space law education is to meet the practical or industrial needs, but the lack of higher education institution offering a specalized degree in air and space law - as the case in China, Indonesia and Thailand - hinders the progress. Even in Italy, space law courses are still very niche and would deserve increased awareness in relation to what educational and professional possibilities a career in space law can offer. Continuous training and other professional development opportunities are essential to ensure that the quality of human resources within the aerospace industry is maintained at its best. This mindset is more relevant for the aviation industry in Indonesia and Thailand; whilst for China and Italy, it is also relevant for the outer space activities since both countries are more advanced in the latter field.

\footnotetext{
95 Institute for International Political Studies.

96 Institute of International Affairs.

97 Distretto Tecnologico Aerospaziale website. https://www.dtascarl.org/en/. [Accessed 3 June 2021].

98 Distretto Aerospaziale della Campania website. http://www.daccampania.com/. [Accessed 3 June 2021].

99 Distretto Aerospaziale della Sardegna website. http://www.dassardegna.eu/. [Accessed 3 June 2021].
} 
Following the rapid development of the aviation industry, air law expertise is also important for the government which mostly deals with the public sector. Stronger expertise on multilateral conventions and freedoms of the air might shape the country's aviation policy. Other emerging global issues are aviation environment, particularly the Carbon Offsetting and Reduction Scheme for International Aviation, ${ }^{100}$ as well as more civilian unmanned aircraft utilization. Meanwhile, in the private sector, the effort to enhance and harmonize passengers' rights through domestic law and international convention deserves more attention. All four selected countries have its domestic law implementing the Montreal Convention of 1999 and another set of law on air passengers' rights either for domestic or international routes. ${ }^{101}$ This situation means extra homework for all stakeholders in determining the best practice.

When it comes to new or unsolved legal difficulties and legal vacuum, universities can undertake research and compare foreign country practices. This should be even the more efficient when the socio-political context allows for close collaborations and shared programs between universities in different countries - hence already in possess of a deep knowledge and awareness of the legal environment of their respective country - such as in the case of the European Union, of which Italy is a founding member.

Bridging academia with professionals is one of the keys to improve the aerospace industry. At one point, university should look outside of its ivory tower and realize that collaboration between academia and the industry is inevitable. Opening doors for managerial position might be worth considering, just like the late Air and Space Law Professor of Universiteit Leiden, Henri Wassenbergh, who played a critical role in KLM's achievements as Dutch flag carrier during that period. ${ }^{102}$ However, university statutes must also accommodate this breakthrough. In July 2021, the rector of Universitas Indonesia was found improper of holding a dual position as the deputy president commissioner of Bank Rakyat Indonesia, a case of conflict of interest which ended in his resignation as the latter. ${ }^{103}$ It is time to establish a proper code of conduct to balance conflict of interest with the opportunity for innovation.

100 For ASEAN see Ridha Aditya Nugraha (2018). Preserving the Environment within the ASEAN Skies: Lessons from the European Union Emissions Trading Scheme. Hasanuddin Law Review, 4(1): 15 - 29. http://pasca.unhas.ac.id/ojs/index.php/halrev/article/viewFile/1343/361. [Accessed 13 September 2021].

101 Ridha Aditya Nugraha and Lalin Kovudhikulrungsri (2017). Aviation Legal Issues in Indonesia and Thailand: Towards Better Passengers' Rights in ASEAN. Indonesia Law Review 23(1): 23 - 48. https://heinonline.org/HOL/LandingPage?handle=hein.journals/indolawrev7\&div=4\&id=\&page. [Accessed 13 September 2021]; Norton Rose Fullbright (2017). Developments in air passenger protection in the People's Republic of China. https://www.nortonrosefulbright.com/en/knowledge/publications/ac595e81/developments-in-airpassenger-protection-in-the-peoples-republic-of-china. [Accessed 25 September 2021].

102 Universiteit Leiden. (2010). IN MEMORIAM Professor Dr. Henri A. (Or) Wassenbergh. https://www.universiteitleiden.nl/en/news/archive/2014/03/in-memoriam-professor-dr--henri-a---or-wassenbergh. [Accessed 25 September 2021].

103 Aqil, A. Muhammad Ibnu (22 July 2021). UI Rector resigns from BRI amid backlash over new university statute. The Jakarta Post. https://www.thejakartapost.com/news/2021/07/22/ui-rector-resigns-frombri-amid-backlash-over-new-university-statute.html. [Accessed 13 September 2021]. 
At the same time, allowing practitioners to be an adjunct professor at the undergraduate and graduate levels will insightfully inspire students to pursue careers in the aviation and space industries. This flexibility, nevertheless, is unlikely to happen in case of Thailand due to regulatory barriers which limit a teaching-hour ratio of guest lecturers per class and require them to publish at least one article in an academic journal every five years in order to teach at graduate level. ${ }^{104}$ Transfer of knowledge and experience might not take place as professionals hardly have time to publish academic articles.

In terms of legal hurdles, Indonesia and Thailand show a vastly different scenario from Italy and China, which may, to some extent, relate to how the students in air and space law are being nurtured. Thus, universities need more flexibility and autonomy to maximize the human resources between academia and the industry in order to bring the best of both worlds.

\section{Conclusion}

Past history has already demonstrated how the academic field plays a pivotal role in shaping the approach to political, juridical, socio-economical, and even technical matters when it comes to aerospace activities. As the general public becomes more familiar with the aerospace industry and its advanced exploration, universities in both developing and developed countries are seeing an emerging future of air and space law. China, Indonesia, Italy, and Thailand share a similar trend, where air and space law education is moving forward towards a more advanced status. Higher education should facilitate this development by establishing a more integrated system, from bridging professionals as guest lecturer in air and space law course and vice versa. Establishing and consolidating a direct link between academia and the industry would mean reducing the gap between the fast evolution of aerospace activities and the need to give them a legal framework, benefitting both in the process.

\section{References}

Administrator. (n.d.), Diritto dei trasporti. Istituto di diritto della navigazione. http://www.dirittodeitrasporti.it/index.php?option=com content\&view=article\&i $\mathrm{d}=34 \&$ Itemid=63. [Accessed 3 June 2021].

Agenzia Spaziale Italiana website. https://www.asi.it/en/education/academy/. [Accessed 3 June 2021].

Agreement on the Rescue of Astronauts, the Return of Astronauts and the Return of Objects Launched into Outer Space, Opened for signature in London, Moscow, and Washington, D.C. on 22 April 1968. Available online from: https://aerospace.org/sites/default/files/policy archives/Assistance\%20Agreeme nt\%20Apr68.pdf.

104 Notification of Thailand Ministry of Education on Standard Criteria for Graduate Studies B.E. 2558 (2015), section 10.3.5. 
Alippi, C., \& D’Amelio, M. (1938). AERONAUTICA in "Enciclopedia Italiana", (I, p. 594). https://www.treccani.it/enciclopedia/aeronautica_res-2a49a99e-8b74-11dc8e9d-0016357eee51 \%28Enciclopedia-Italiana\%29/. [Accessed 3 June 2021].

APSCO, Degree Education. http://www.apsco.int/html/comp1/content/Education/201807-02/41-164-1.shtml. [Accessed 14 June 2021].

Aqil, A. Muhammad Ibnu. (2021). UI Rector resigns from BRI amid backlash over new university statute. The Jakarta Post. https://www.thejakartapost.com/news/2021/07/22/ui-rector-resigns-from-briamid-backlash-over-new-university-statute.html. [Accessed 13 September 2021].

AU School of Law Website. (2021). Bachelor of Laws Program. Available online from: http://www.law.au.edu/program-llb-thai.html. [Accessed August 16, 2021].

AU School of Law Website. (2021). Master of Laws Program. Available online from: http://www.law.au.edu/program-Ilm-thai.html. [Accessed August 16, 2021].

Bangprapa, Mongkol (2020). Cabinet approves draft Space Affairs Bill. Bangkok Post. https://www.bangkokpost.com/thailand/general/2148599/cabinet-aproves-draftspace-affairs-bill. [Accessed 1 August 2021].

Centre for Aviation (2020). China becomes the largest aviation market in the world. https://centreforaviation.com/analysis/reports/china-becomes-the-largestaviation-market-in-the-world-521779. [Accessed 17 July 2021].

Chiang Mai University, NIDA, and Dhurakij Pundit University do not offer any. See Faculty of Law, CMU Website. (2018). Master of Laws Program. Available online from: https://www.law.cmu.ac.th/law2011/downloads/master-coursestructure2561.pdf. [Accessed August 16, 2021].

China University of Political Science and Law. Brief Introduction. http://en.cupl.edu.cn/About CUPL/Brief Introduction.htm. [Accessed 14 August 2021].

Civil Aviation Law of the People's Republic of China, adopted at the 16th Session of the Standing Committee of the Eighth National People's Congress on October 30, 1995; and last amended on April 29, 2021.

Convention for the Unification of Certain Rules for International Carriage by Air, done in $\begin{array}{llll}\text { Montreal, } & 28 & \text { May } & 1999 .\end{array}$ https://www.iata.org/contentassets/fb1137ff561a4819a2d38f3db7308758/mc99full-text.pdf.

Dhurakij Pundit University Website. (2019). Master of Laws Program. Available online from: $\quad$ https://www.dpu.ac.th/IIm/documents/Master\%20of\%20Laws.pdf. [Accessed August 16, 2021].

Distretto Aerospaziale della Campania website. http://www.daccampania.com/. [Accessed 3 June 2021].

Distretto Aerospaziale della Sardegna website. http://www.dassardegna.eu/. [Accessed 3 June 2021].

Distretto Tecnologico Aerospaziale website. https://www.dtascarl.org/en/. [Accessed 3 June 2021]. 
Division of Academic Affairs Naresuan University. (2017). Bachelor of Laws Program. Available online from: https://www.acad.nu.ac.th/acad V2.1/ACAD AcademicDevelop/acadcd/StdManu al 2560/files/cluster/soc/01 laws/60/\%E0\%B8\%A1\%E0\%B8\%84\%E0\%B8\%AD.2\%E0\%B8\%AB\%E0\%B8\%A5\%E0\%B8\%B1\%E0\%B8\%81\%E0\%B8\%AA\%E0\%B8\%B9\%E0 \%B8\%95\%Е0\%B8\%A3\%E0\%B8\%99\%E0\%B8\%B4\%E0\%B8\%95\%E0\%B8\%B42560.pdf. [Accessed August 16, 2021].

Dubai International Financial Centre, Courts of Space launches into orbit in support of global space economy. https://www.difc.ae/newsroom/news/courts-spacelaunches-orbit-support-global-space-economy/. [Accessed 15 June 2021].

European Space Agency. (2016). What is space 4.0? https://www.esa.int/About_Us/Ministerial_Council_2016/What is space_4.0. [Accessed 17 July 2021].

European Space Agency, Institutions Teaching Space Law. http://www.esa.int/About Us/ECSL -

European_Centre for Space_Law/Institutions teaching Space Law. [Accessed 3 June 2021].

European Space Agency, University of Padua. http://www.esa.int/About Us/ECSL European_Centre for Space_Law/University of Padua. [Accessed 3 June 2021].

European Space Agency, Careers at ESA. http://www.esa.int/About Us/Careers at ESA. [Accessed 3 June 2021].

Fabbrini, F. (1982). COGLIOLO, Pietro in Dizionario Biografico degli Italiani - Volume 26 https://www.treccani.it/enciclopedia/pietro-cogliolo_\%28DizionarioBiografico\%29/. [Accessed 3 June 2021].

Faculty of Engineering Kasetsart University Website. (2017). Bachelor of Science Program in Aviation Technology Management. Available online from: https://www.eng.ku.ac.th/wp-content/uploads/2020/10/BThai-25AT-Special.pdf. [Accessed August 16, 2021].

Faculty of Humanities and Social Sciences, Udon Thani Rajabhat University Website. (2021). Bachelor of Laws. Available online from: http://human.udru.ac.th/website/wpcontent/uploads/2021/07/\%E0\%B8\%84\%E0\%B8\%B9\%E0\%B9\%88\%E0\%B8\%A1\%E 0\%B8\%B7\%E0\%B8\%AD\%E0\%B8\%AA\%E0\%B8\%B2\%E0\%B8\%82\%E0\%B8\%B2\%E0\% B8\%A7\%Е0\%B8\%B4\%E0\%B8\%8A\%E0\%B8\%B2\%Е0\%B8\%99\%Е0\%B8\%B4\%E0\%B8\%95\%E0\%B8\%B4\%E0\%B8\%A8\%E0\%B8\%B2\%E0 \%B8\%AA\%E0\%B8\%95\%E0\%B8\%A3\%E0\%B9\%8C-64.pdf. [Accessed August 16, 2021].

Faculty of Law Ramkhamhaeng University Website. (2017). Master of Laws. Available online from: http://www.law.ru.ac.th/document/master.pdf. [Accessed August 16, 2021].

Faculty of Law Ramkhamhaeng University Website. (2020). Bachelor of Laws and Associate Degree Program in Laws. Available online from: http://www.law.ru.ac.th/document/bachelor.pdf. [Accessed August 16, 2021].

Hallinen, J. (2015, October 21). STEM in Encyclopædia Britannica, Inc. (2021). https://www.britannica.com/topic/STEM-education. [Accessed 3 June 2021]. 
International Air Transport Association (IATA) Website. (1929). Convention for the Unification of certain rules relating to international carriage by air. Available online from:

https://www.iata.org/contentassets/fb1137ff561a4819a2d38f3db7308758/mc99full-text.pdf. [Accessed July 17, 2021].

International Air Transport Association (IATA) Website. (1999). Convention for the Unification of Certain Rules for International Carriage by Air. Available online from: https://www.iata.org/en/policy/smarter-regulation/mc99/. [Accessed July 17, 2021].

International Civil Aviation Organization Website. (1944). Convention on International Civil Aviation. Available online from: https://www.icao.int/publications/documents/7300_orig.pdf. [Accessed July 17, 2021].

International Civil Aviation Organization Website. List of Parties to the Convention on International Civil Aviation. Available online from: https://www.icao.int/secretariat/legal/List\%20of\%20Parties/Chicago_EN.pdf. [Accessed July 17, 2021].

International Civil Aviation Organization Website. List of Parties to the Convention for the Unification of Certain Rules for International Carriage by Air. Available online from: https://www.icao.int/secretariat/legal/List\%20of\%20Parties/Mtl99 EN.pdf. [Accessed July 17, 2021].

International Civil Aviation Organization Website. The Postal History of ICAO. Available online from: https://applications.icao.int/postalhistory/1944 the chicago convention.htm. [Accessed July 17, 2021].

Laksmana, Evan (2019). Indonesia as "Global Maritime Fulcrum": a Post-Mortem Analysis. Asia Maritime Transparency Initiative. https://amti.csis.org/indonesia-as-globalmaritime-fulcrum-a-post-mortem-analysis/. [Accessed 17 July 2021].

Law Chula Website. (2019). Master of Laws Program. Available online from: https://www.law.chula.ac.th/wp-content/uploads/2019/06/น.ม-รายวิชาลงทะเบียนเรียนภาค การศึกษาต้น-ปีการศึกษา-2562.pdf. [Accessed August 16, 2021].

Law Chula Website. (2020). Bachelor of Laws Program. Available online from: https://www.law.chula.ac.th/wp-content/uploads/2021/02/คู่มือหลักสูตรปริญญาตรีปีการศึกษา-2563.pdf. [Accessed August 16, 2021].

Law Chula Website. (2020). Bachelor of Laws Program. Available online from: https://www.law.chula.ac.th/wp-content/uploads/2021/02/คู่มือหลักสูตรปริญญาตรี-ปี การศึกษา-2563.pdf. [Accessed August 16, 2021].

Law Pridi Dhurakij Pundit University Website. (2020). Bachelor of Laws Program. Available online from: https://law.dpu.ac.th/upload/content/files/CoursestructureLaw2563.pdf. [Accessed August 16, 2021].

McGill Institute of Air \& Space Law Website. Class Lists by Country. Available online from: https://www.mcgill.ca/iasl/about/alumni/list/country\#thailand. [Accessed July 17, 2021]. 
Mongkol Bangprapa. (2021). Cabinet approves space bill, Available Online from: https://www.bangkokpost.com/thailand/general/2148811/cabinet-approvesspace-bill [Accessed July 17, 2021].

National Aeronautics and Space Administration. San Marco 1. https://nssdc.gsfc.nasa.gov/nmc/spacecraft/display.action?id=1964-084A. [Accessed 3 June 2021].

Norton Rose Fulbright (2017). Developments in air passenger protection in the Peoples' Republic of China. Available online from: https://www.nortonrosefulbright.com/en/knowledge/publications/ac595e81/dev elopments-in-air-passenger-protection-in-the-peoples-republic-of-china. [Accessed 25 September 2021].

Notification of Thailand Ministry of Education on Standard Criteria for Graduate Studies B.E. 2558 (2015), section 10.3.5.

NIDA School of Law Website. (2017). Master of Laws Program. Available online from: http://law.nida.ac.th/statics/ui/files//336c373bab696fcf211eaf3eb3dcd989.pdf. [Accessed August 16, 2021].

Office of the Register Website, Thammasat University. (2013). Bachelor of Laws Program. Available online from: https://reg.tu.ac.th/th/Picture/AttFile/c9b0a12f-81e0-4d4792ba-079e30983576. [Accessed August 16, 2021].

Office of the Register Website, Thammasat University. (2013). Master of Laws Program. Available online from: https://reg.tu.ac.th/th/Picture/AttFile/c113296d-c2c64641-8c13-c0f1b28479be. [Accessed August 16, 2021].

Office of the Register Website, Thammasat University. (2018). Bachelor of Laws Program. Available online from: https://reg.tu.ac.th/th/Picture/AttFile/d22829be-05e54089-8d3f-5267c9656827. [Accessed August 16, 2021].

Office of the Register Website, Thammasat University. (2018). Bachelor of Laws Program. Available online from: https://reg.tu.ac.th/th/Picture/AttFile/d22829be-05e54089-8d3f-5267c9656827. [Accessed August 16, 2021].

Office of the Register Website, Thammasat University. (2018). Bachelor of Laws Program. Available online from: https://reg.tu.ac.th/th/Picture/AttFile/d22829be-05e54089-8d3f-5267c9656827. [Accessed August 16, 2021].

Registrar Division Mae Fah Luang University Website. (2012). Bachelor of Laws Program. Available online from: https://bit.ly/3FUNLwX. [Accessed August 16, 2021].

Registrar Division Mae Fah Luang University Website. (2012). Master of Laws Program. Available online from: $h$ ttps://bit.ly/2ZwX4se [Accessed August 16, 2021].

Registrar Division Mae Fah Luang University Website. (2021). Bachelor of Laws Program. Available online from: https://reg.mfu.ac.th/registrar/class info 2.asp?courseid=1705215273\&backto=h ome\&nosection=1. [Accessed August 16, 2021].

Nugraha, Ridha Aditya, and Lalin Kovudhikulrungsri. "Aviation Legal Issues in Indonesia and Thailand: Toward Better Passengers' Rights in ASEAN." Indon. L. Rev. 23 no. 1 (2017): 23-48.

Nugraha, Ridha Aditya. "Preserving the Environment within the ASEAN Skies: Lessons from the European Union Emissions Trading Scheme." Hasanuddin Law Review 4, no. 1 (2018): 15-29. 
Nugraha, Ridha Aditya. "The Indonesian Aviation Sector in the Realm of Liberalisation: The Long and Winding Road." In Aviation Law and Policy in Asia, pp. 253-268. Brill Nijhoff, 2020.

School of Law University of Phayao. (2020). Bachelor of Laws Program. Available online from: https://bit.ly/3p9oybt. [Accessed August 16, 2021].

Sezione Roma 2. Gen. Isp. C. Genio Aeronautico Luigi Broglio. http://www.romaduebroglio.eu/biografia/. [Accessed 3 June 2021].

Sgrosso, G. C. (2011). Diritto internazionale dello spazio. LoGisma. Società italiana di diritto internazionale. http://www.sidi-isil.org/wpcontent/uploads/2010/06/Presentazione10.pdf. [Accessed 3 June 2021].

Società Italiana per I'organizzazione Internazionale, Master's Course in Space Institutions and Policies. https://www.sioi.org/master_corsi/masteri-in-istituzioni-e-politichespaziali/?lang=en. [Accessed 3 June 2021].

Società Italiana per l'organizzazione Internazionale website. https://www.sioi.org/?lang=en. [Accessed 3 June 2021].

Società Italiana per l'organizzazione Internazionale website. https://www.sioi.org/primopiano/master-in-istituzioni-e-politiche-spaziali-on-line-il-bando-per-3-borse-distudio/?lang=en. [Accessed 25 September 2021].

Starlink. Order Starlink. https://www.starlink.com/. [Accessed 17 July 2021].

Thailand Notification of Thailand Ministry of Education on Standard Criteria for Graduate Studies B.E. 2558 (2015).

The Eastern Economic Corridor of Innovation Website. (2021). Focused Industries. Available online from: https://www.eeci.or.th/en/home/. [Accessed August 16, 2021].

Tullio, L. (n.d.). Documenti per la storia dell'Istituto di diritto della navigazione dell'Università La Sapienza di Roma. https://www.fog.it/articoli/02-0125.pdf. [Accessed 3 June 2021].

Tullio, L. (n.d.). Storia dell'Istituto. https://www.fog.it/istituto/storia.html. [Accessed 25 September 2021].

United Nations Convention on the Law of the Sea, done in Jamaica, 10 December 1982. https://www.un.org/depts/los/convention agreements/texts/unclos/UNCLOSTOC.htm

United Nations Office for Outer Space Affairs Website. (1967). Treaty on Principles Governing the Activities of States in the Exploration and Use of Outer Space, including the Moon and Other Celestial Bodies. Available online from: https://www.unoosa.org/oosa/en/ourwork/spacelaw/treaties/introouterspacetre aty.html. [Accessed July 17, 2021].

Università degli studi di Bari website. https://www.uniba.it/english-version. [Accessed 3 June 2021].

Università degli studi di Bergamo, La parola agli student - Scegliere. https://lmgiu.unibg.it/it. [Accessed 3 June 2021]

Università degli studi di Ferrara website. http://www.unife.it/giurisprudenza/giurisprudenza. [Accessed 3 June 2021].

Università degli studi di Genoa, Laurea Magistrale a Ciclo Unico, Giurisprudenza Genova. https://corsi.unige.it/7995. [Accessed 3 June 2021] 
Università degli studi di Messina website. https://international.unime.it/. [Accessed 3 June 2021].

Università degli studi di Milano website. https://en.unimib.it/. [Accessed 3 June 2021].

Università degli studi di Padua website. http://www.unipd.it/en. [Accessed 3 June 2021].

Università degli studi di Roma "Sapienza" website. https://www.uniroma1.it/en/paginastrutturale/home. [Accessed 3 June 2021].

Università degli studi di Sassari website. https://www.unime.it/it/dipartimenti/giurisprudenza. [Accessed 3 June 2021].

Università degli studi di Udine website. https://www.uniud.it/en/uniudinternational?set language=en. [Accessed 3 June 2021].

Università degli studi di Verona, Combined Bachelor's + Master's Degree in Law. https://www.corsi.univr.it/?ent=cs\&id=274\&lang=en. [Accessed 3 June 2021]

Università di Bologna website. https://www.unibo.it/en/homepage.[Accessed 3 June 2021].

Università di Bologna, Course Unit Catalogue: Air and Space Law 2020/2021. https://www.unibo.it/en/teaching/course-unit-catalogue/courseunit/2020/461805. [Accessed 3 June 2021].

Universiteit Leiden. (2010). IN MEMORIAM Professor Dr. Henri A. (Or) Wassenbergh. https://www.universiteitleiden.nl/en/news/archive/2014/03/in-memoriamprofessor-dr--henri-a---or--wassenbergh. [Accessed 25 September 2021].

UTCC School of Law Website. (2021). Bachelor of Laws Program. Available online from: https://law.utcc.ac.th/ll-b/\#1589449413315-6c8e8c13-1f1f. [Accessed August 16, 2021].

UTCC School of Law Website. (2021). Master of Laws Program. https://law.utcc.ac.th/II-

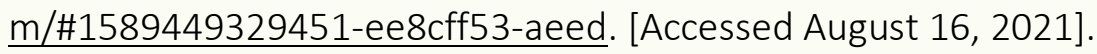

Conflict of Interest Statement: The author(s) declares that the research was conducted in the absence of any commercial or financial relationship that could be construed as a potential conflict of interest.

Copyright: (C) HALREV. This is an open access article distributed under the terms of the Creative Commons Attribution 4.0 International License (CC-BY 4.0), which permits unrestricted use, distribution, and reproduction in any medium, provided the original author and source are credited.

Hasanuddin Law Review (Hasanuddin Law Rev. - HALREV) is an open access and peer-reviewed journal published by Faculty of Law, Hasanuddin University, Indonesia. 